\title{
The Ability to Think Creatively on SSCS Using Schoology Apps, How is the Student's Language Metacognitive Awareness?
}

\author{
Kundharu Saddhono $^{1 *}$, Cahyo Hasanudin ${ }^{2}$, Ayu Fitrianingsih ${ }^{3}$ \\ ${ }^{1}$ Graduate School of Universitas Sebelas Maret Surakarta, 57126, Indonesia \\ ${ }^{2}$ Indonesian Language and Literature Education Department, IKIP PGRI Bojonegoro, 62114, Indonesia \\ ${ }^{3}$ English Education Department IKIP PGRI Bojonegoro, 62114, Indonesia
}

Corresponding Author Email: kundharu_s@staff.uns.ac.id

https://doi.org/10.18280/isi.240402

Received: 18 April 2019

Accepted: 9 July 2019

\section{Keywords:}

creative thinking, metacognitive awareness, schoology apps, search, solve, create and share (SSCS) learning

\section{INTRODUCTION}

Creative thinking is always needed in everything, especially in solving questions given by the lecturer. Students are able to solve the problems easily using creativity. Creativity is interpreted as a person's attitude and ability in creating new product [1]. The new products, that are in form of new ideas, can be generated from the composition of previous ideas [2]. These new ideas can be produced by students who have the ability to think creatively in solving complex problems.

Creative thinking is a form of mental work to create ongoing relationships that produce the best combination [3]. The product of creative thinking has two elements, namely fluency and flexibility [4]. Fluency can be viewed from many ideas generated in solving problems, then flexibility can be examined from a variety of different ideas in solving problems.

Olson divides creative thinking into four levels, namely 1) The fourth level of ability to think creatively. This level can be said to be very creative level, students at this level are able to solve problems with multiple answers and raise different problems flexibly, 2) The third level of ability to think creatively. This level can be said to be creative level, students at this level are able to make new answers by solving different problems even though they are not fluent [5]. They are also able to make new answers by solving the same problem, and able to make different problems even though the answer is only one. It can be said that they are able to make a new problem with a variative answer. 3) The second level of ability to think creatively. This level can be said as quite creative level. Students at this level are able to make an answer and problem based on their habitual activities. They are able to arrange different solutions fluently but not the new one, 4) The first level of ability to think creatively. This level can be said to be less creative level, students at this level cannot make alternative solutions and different problems, even though one indicator is fulfilled.

Tatag also added zero (0) level of ability to think creatively. This level can be said as non-creative level. Students at this level are unable to make alternative solutions and solve different problems flexibly.

The concept of creative thinking has been initiated by experts. Since this theory emerged, researchers have studied a lot about the ability to think creatively. Creative thinking can be developed through human awareness that leads to the habit of using creative thoughts [6].

This habit is very closely related to the students' metacognitive abilities. In general, metacognitive is related to awareness in thinking and the ability to use it in regulating thought processes [7]. Metacognitive is the students' ability to know themselves as learners, so that they can control and adjust what they think [8]. A person's thought consists of metacognitive knowledge, metacognitive skill, and metacognitive experience [9]. Amin and Sukestiyarno explain that there are positive linear relationships between 1) metacognitive awareness and cognitive skill, 2) metacognitive awareness and metacognitive skill, and 3) cognitive skill and metacognitive skill with sufficient criteria/ medium [10].

The level of metacognitive awareness in the thought process based consists of four levels, namely: 1) Level 1: Tacit Use, it is the ability to use mind unconsciously. This is related to make decision without thinking about it [11]. At this level, students give answers unconsciously in solving the problems, 2) Level 2: aware use, it is the ability to use mind consciously. This is related to 'what' and 'when' students must take an action. At this level, the students realize that 
they are able to solve problems using the best solution chosen, 3) level 3: strategic use, it is the ability to use mind in using strategies to improve students' thinking skill. This is related to the use of conscious and strategic thinking. At this level, the students can choose a suitable strategy in solving a problem, 4) level 4: reflective use, it is the ability to use mind in taking decision, the impact that is caused and how to solve it, and reflect all decisions that have been made. At this level, the students realize and correct mistakes made.

Thinking is a process and cognitive product that belongs to a person [12]. How a person learns and processes information is part of the concept of knowledge of metacognitive [13]. Metacognitive is a complex skill needed by students to master special skill in solving problems of different contexts [14] so they become independent learners [15].

Creating independent learners need learning innovation. One of it that can be applied is using SSCS learning model that is collaborated with schoology applications. SSCS is an acronym for search, solve, create, and share. In line with Chen who says that SSCS method is guided on ways to solve problems, it begins with investigating the problems, arranging a problem solving method, building a problem solving pattern, and finally conveying it [16]. SSCS is a model that is very effective and easy to be practiced [17] so the students' abilities to think have increased [18]. SSCS learning model can arouse students' interest and solve problems in real life, in this model students are free and flexible to develop their creativities and thinking skill [19].

The development of creativity and thinking skill is strongly supported by the use of schoology apps. This application is part of learning management system (LMS) which makes it easier for teacher and students to interact wherever and whenever, especially make it easier to deliver materials, answer quizzes, and submit the assignments. The schoology platform was designed by Jeremy Friedman, Ryan Hwan, and the Trinidad team. This platform is free for all educators. The application is part of LMS that can be accessed through iOS, android, and kindle devices. According to Sicat, LMS can develop students' competences [20].

Schoology is an educational media that is very promising to meet current and future challenges, especially the problem of teaching in $21^{\text {st }}$ century [21]. Schoology is a website that combines e-learning and social networking [22]. This social website offers classroom learning and easy to use [23]. The homepage of schoology apps is as follows.

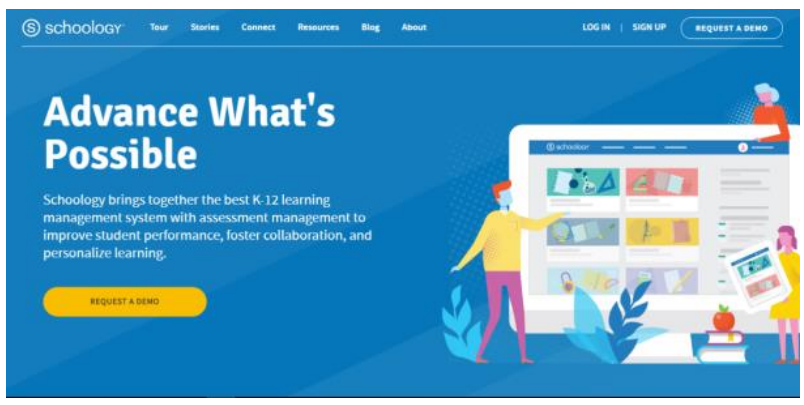

Figure 1. The homepage of schoology apps

The use of schoology apps that is ever implemented can improve students' mathematical literacy skill [24]. Schoology apps can be regarded as an effective media in teaching business writing among university students compared to traditional method [20]. The implementation of schoology apps based on the study can provide benefits for students, including increasing productivities and academic achievements, completing tasks faster, and providing access to learn outside the classroom [25]. The use of schoology apps in SSCS learning about syntax subject has the following learning stages.

Table 1. Sscs learning model using schoology apps

\begin{tabular}{ll}
\hline Phase & \multicolumn{1}{c}{ Sscs using schoology apps } \\
\hline Search & 1. Students understand the problems given \\
& through schoology apps \\
& 2. Students search additional information \\
apart from schoology apps \\
3. Students analyse the information \\
provided in schoology apps
\end{tabular}

Based on the explanations above, the researchers apply SSCS learning using schoology apps in the subject of syntax to know the students' ability to think creatively based on levels of language metacognitive awareness in solving syntax problems in SSCS learning using schoology apps.

\section{METHODOLOGY}

This study is qualitative research with a descriptive approach. The subjects of this study were all $4^{\text {th }}$ semester students of class A in Indonesian Language and Literature Education Department, Faculty of Language and Art Education, IKIP PGRI Bojonegoro. From total of 29 students, 5 students who had good communication skill were interviewed.

Table 2. The level of ability to think creatively (ATC)

\begin{tabular}{ccc}
\hline No. & Subject & Notes \\
\hline 1. & S1 & ATC "0" \\
2. & S2 & ATC "1" \\
3. & S3 & ATC "2" \\
4. & S4 & ATC "3" \\
5. & S5 & ATC "4" \\
\hline
\end{tabular}

Moreover, the subject was taken using a combination of stratified sampling techniques and purposive sampling. Stratified sampling is obtained by using the students' results of written test in schoology apps, it refers to the question grid analysis of students' creative thinking abilities, then, 
combined with purposive sampling to adjust the subjects with the levels of language metacognitive awareness. So, the subjects were suitable with the focus of the study, as follows:

Table 3. The level of metacognitive understanding

\begin{tabular}{|c|c|c|c|c|c|}
\hline \multirow[b]{2}{*}{ No. } & \multirow[b]{2}{*}{ ATC } & \multicolumn{4}{|c|}{ The level of metacognitive awareness } \\
\hline & & $\begin{array}{c}\text { Tacit } \\
\text { use }\end{array}$ & $\begin{array}{c}\text { Aware } \\
\text { use }\end{array}$ & $\begin{array}{c}\text { Strategic } \\
\text { use }\end{array}$ & $\begin{array}{c}\text { Reflective } \\
\text { use }\end{array}$ \\
\hline 1. & ATC“0” & & & & \\
\hline 2. & ATC“1” & & & & \\
\hline 3. & ATC“2” & & & & \\
\hline 4. & ATC“3” & & & & \\
\hline 5. & ATC“4” & & & & \\
\hline
\end{tabular}

When the students are in their own levels of ability to think creatively, all of their activities will be analysed. From their activities, they will be grouped into levels of metacognitive awareness. Based on the results of this analysis, it will be known whether students who are in ATC "4" have a reflective use level or not. If they have not reached this level, the causes will be found. It will be presented as detailed as possible.

\section{DATA SOURCES}

The sources of data in this study are the results of test about the ability to think creatively as a basic knowledge in examining the tendencies of students' metacognitive awareness. It is as a benchmark for students' abilities to think creatively in understanding the concepts of phrases, words, and clauses. The results of interview are used to clarify the students' answers of test, the rest are additional data in observing the learning process of SSCS using schoology apps, and documentations.

\section{DATA COLLECTION TECHNIQUE}

\subsection{Test method}

Essay test is used to answer the information about the level of ability to think creatively in solving problems about phrases, clauses, and sentences. The use of essay test was compiled by the researchers, with prior consultation and validation by lecturers of Indonesian Language and Literature Education Department, IKIP PGRI Bojonegoro so the test questions were suitable to the materials to be tested. Tests given to students are long essay tests derived from short stories, song lyrics, or opinions with the number of questions is only one. Long essay test is chosen because in answering questions about phrase, clause, and sentence takes a long process with several stages and one question have represented all levels of students' abilities to think creatively. The stages in collecting data through test are: 1) Preparing test questions, 2) Uploading the questions to schoology apps, 3) Supervising students' works in solving problems or questions in the application, 4) Correcting and categorizing test results, 5) Analysing the test results.

\subsection{Interview method}

The interview method in this study was unstructured interview. It has been chosen because it is suitable for students, in which they are more likely to tell their abilities and difficulties in solving problems. In addition, this interview is free, so students do not feel bored in sharing problems, and has interview guidelines. The interview was conducted directly to the students to examine the students' errors in answering the test and know the factors that caused the errors.

\subsection{Observation}

This method is used to observe directly the conditions in the setting of study to get a broader view about the problem. This study uses direct observation in which the researchers observe the implementation of SSCS in the classroom and supervise students in doing assignments in schoology apps.

\section{RESEARCH INSTRUMENTS}

The instruments in this study are test questions, interview and observation guidelines. The test questions are used to know the students' levels of metacognitive awareness in solving syntax problems. The interview guidelines are used to interview the students as a process of clarifying answers. The observation guidelines are used to find out the students' conditions in taking class with SSCS learning model using schoology apps.

\section{DATA ANALYSIS TECHNIQUES}

The data obtained in this study were the results of test and interview. After the data is collected, a data reduction is conducted to focus on the things that will be examined, namely analysing the whole students' answers. Data analysis was carried out descriptively, based on criteria from [11] that consists of four levels, namely: 1) Level 1: Tacit Use, 2) Level 2: aware use, 3) level 3: strategic use, 4) level 4: reflective use. The content analysis method of [26] is described as components of data analysis: Flow Model that consists of three activities, 1) data reduction; 2) data presentation; and 3) drawing conclusions/ verification. The Flow Model has three components that are interconnected well, namely, before, during, and after collecting data.

At the stage of data reduction, the researchers 1) view the results of students' works on the schoology apps, 2) conduct interviews with several subjects of the study, and its results are simplified into good language arrangements. At the stage of data presentation, the researchers 1) present the students' work results that have been selected as research subjects, 2) present the results of interview that have been recorded on mobile phone. At the last stage, the researchers compare the results of students' works and the results of interview. It can be concluded about the levels of students' cognitive understanding.

\section{CHECKING THE VALIDITY OF THE FINDINGS}

According to Azwar [27] validity is an assessment of the accuracy of a measurement for inference or specific decisions resulting from the score produced. Checking the validity of the data in this study uses the techniques of data source and method triangulations. The data source triangulation was 
carried out by interviewing the subjects of the study and comparing its results with the students' works in schoology apps. In method triangulation, the researchers conducted a test on the level of students' language metacognitive understanding and interviewed the students of II $\mathrm{A}$ in Indonesian Language and Literature Education Department, then the results of test and interview were categorized based on the levels of metacognitive awareness according to Swartz and Perkins [11], namely tacit use, aware use, strategic use, and reflective use.

\section{RESULTS AND DISCUSSION}

\subsection{Results}

Based on the Level of Ability to Think Creatively (ATC) by Tatag, the followings are explanations about every level that shows students' ability to think creatively in syntax subject with SSCS learning model using schoology apps.

At LATC 0, the students seem not to be creative, they are unable to modify the words in the song lyrics. The song lyric that is used as question is the song of Kekasih Bayangan by Cakra Khan. The students' written sentences in schoology apps are based on the questions showed in the following picture.

$$
\text { 4. - Kau(s) jadikan(p) aku kekasih bayangan(o) }
$$

Figure 2. The answer of the $1^{\text {st }}$ subject

In the schoology apps, the first student wrote $\frac{\text { Kau Jadikan }}{S} \frac{\text { aku kekasih bayangan }}{P}$. Based on this answer, it showed that the student had not been able to modify the words in the song lyrics and the syntactic functions provided were also incorrect. The alternative answer to the song lyrics written by the student based on the questions had to be $\frac{\text { Kau Jadikan }}{S} \frac{\text { aku kekasih bayangan }}{O} \frac{\text { dalam hidup ini }}{\text { Kel. }}$. When the researchers asked him the reasons for giving the answer, he explained that he got confused to add the words and uncomprehend the syntactic functions of the new sentences. This can be shown in the following interview transcript.

$\mathrm{P}$ : "Apakah kamu pernah mendengarkan lagu itu, Saudara?" (Have you ever heard that song?)

S1: "Sudah, Pak!" (Actually, Sir!)

P : “Artinya, Saudara tentu tahu lirik lagu tersebut kan?" (It means you certainly know the song lyric, right?)

S1: “ya, Pak, saya tahu." (Yes,Sir. I know.)

$\mathrm{P}$ : "Mengapa Saudara tidak menambahkan kata-kata sesuai dengan perintah soal?" (why don't you add new words based on the questions?)

S1: "Saya bingung ingin nenambahkan kata-kata di bagian fungsi sintaksis yang mana, jujur saja, saya masih bingung dengan fungsi sintaksis yang ada." (I am confused about adding new words using syntactic functions)

In ATC 1, students seem less creative, they have not been able to make alternative answers to the three questions given about finding the examples of phrases, compound words, and idioms. The answers can be seen in the following pictures.

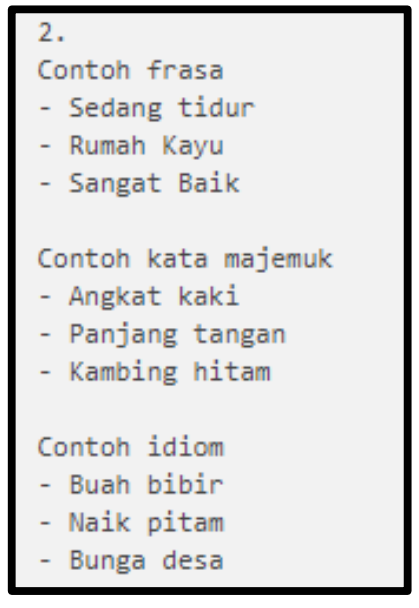

Figure 3. The answer of the $2^{\text {nd }}$ subject

In the schoology apps, the student wrote the example of phrases and idions correctly, but the examples of compund words were still incorrect. The answers that were written as "Angkat kaki", "panjang tangan", and "kambing hitam" were not the examples of compound words, it was idioms. Inaccuracy in giving the answer indicated that students hhad not been able to make alternative answers to the questions given. When the researchers asked about the reasons for giving the answer, he explained that he did not know the alternative answers that must be given to the example of a compound word. They had not been able to distinguish between idioms and compound words, as shown in the following interview transcript.

$\mathrm{P}$ : "Apakah saudara sudah membaca materi di aplikasi schoology?" (have you read the materials on the schoology application?)

S2 : "Sudah, Pak!" (Already, Sir!)

$\mathrm{P}$ : "Mengapa jawaban yang saudara berikan masih belum tepat?" (Why do you give the incorrect answer?)

S2 : "Jawaban mana yang belum tepat ya, Pak?" (Which one, Sir?)

$\mathrm{P}$ : "Saudara masih belum tepat dalam menempatkan contoh kata majemuk, contoh tersebut dapat digolongkan ke dalam idiom". (You haven't put the compound words in good order, it can be classified into idioms)

S2 : "Maaf, Pak, saya masih belum memahami makna kata majemuk, sehingga jawaban yang saya berikan belum tepat”. (Sorry, Sir. I still don't understand about compound words, that's why I give the wrong answer.)

In ATC 2, the students are quite creative in answering the questions in schoology apps about finding single sentences and compound sentences from a short story entitled "Tarian Air dan Api" by Ikhwanul Halim. They are able to distinguish single sentences and compound sentences well, and able to provide the syntactic functions appropriately. The answers can be seen in Figure 4.

In Figure $4 \mathrm{a}$, the student was able to provide syntactic functions correctly in single sentence, it was in SPOK (Subject, Predicate, Object, Adverb). In Figure 4b, the student was also able to provide syntactic functions correctly in compound sentence, it was in SPOSPO. In the student's written sentence, it matched to the short story. However, when the compound sentence was broken down, it would 
have a syntactic function like this $\frac{\text { Kami }}{S} \frac{\text { membuat }}{P} \frac{\text { naga }}{O} \frac{\text { dan }}{\text { konj. }} \frac{\text { kami }}{S} \frac{\text { membuat }}{P} \quad \frac{\text { kereta kencana }}{O}$. It indicated that there is a repetition of the same words in subject and predicate of the sentence. It would be more effective when there was no conjunction after the subject (S) and predicate $(\mathrm{P})$. Thus, it could be said that the students were able to solve different questions from a short story. Even though they did not produce new words, they were quite creative in giving answer. When the researchers asked him the reasons for giving the answer, he explained that he could distinguish between single and compound sentences. He was also able to provide syntactic functions in every sentence he wrote. It could be shown in the following interview script.

$\mathrm{P}$ : "Apakah saudara sudah bisa membedakan kalimat tunggal dan majemuk?" (Can you distinguish between single and compound sentence?)

S3: "Sudah, Pak!'” (Yes, I can Sir.)

P : "Apakah ciri-ciri kalimat tunggal itu?" (what is the characteristic of a single sentence?)

S3: "Kalimat yang tidak memiliki konjungi". (The sentence has no conjunction.)

P : "Apakah ciri-ciri kalimat majemuk?" (what are the characteristics of compound sentence?)

S3: "Kalimat majemuk terdiri atas 3, yaitu kalimat majemuk setara, bertingkat, dan campuran. Ketika saya membaca soal pada aplikasi schoology untuk mencari kalimat majemuk setara, saya hanya melihat konjungi kalimat pada cerpen "Tarian Air dan Api" karya Ikhwanul Halim. Di sana saya menemukan kalimat dengan menggunakan konjungi 'dan'. Kalimat dengan menggunakan konjungi 'dan' merupakan salah satu ciri dari kalimat majemuk setara. (It consists of 3 sentences, namely compound, complex, and compound complex sentences. When I read the questions in schoology apps to find the compound complex, I just see the conjunctions of the sentences in the short story entitled "Tarian Air dan Api" by Ikhwanul Halim. There, I found the sentences that using conjunction "and". This sentence belonged to compound sentence.)

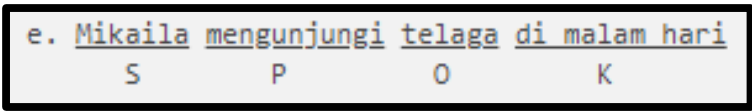

(a)

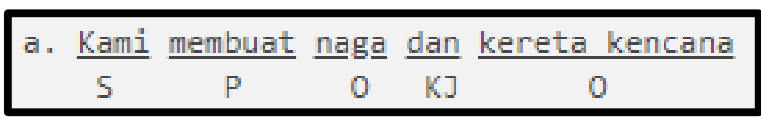

(b)

Figure 4. a) The answer of the $3^{\text {rd }}$ subject; b) The answer of the $3^{\text {rd }}$ subject

In ATC 3, the students are creative in giving answers through the schoology apps about arranging good sentences using the words provided. Those words are "di kamar", "ular", "bapak", "mati”, "digigit", and "ibu”. Students provide varied answers with several alternative solutions. In addition, they are able to provide the syntactic functions of the sentences appropriately. The answer can be shown in the following figure.
1. Kalimat dan fungsi Sintaksis

Ular mati (s) digigit (p) bapak dan ibu (o) di kamar (k)

Bapak (s) digigit (p) ular mati (o) di kamar ibu (k)

Figure 5. The answer of the $4^{\text {th }}$ subject

In Figure 5, the student provides varied answers. In the first answer, she writes compound sentence by giving its syntactic functions correctly. When it is broken down, it will be $\frac{\text { Ular mati }}{S} \frac{\text { digigit }}{P} \frac{\text { bapak }}{O} \frac{\text { dan }}{\text { konj. }} \frac{\text { Ular mati }}{S} \frac{\text { digigit }}{P} \frac{\text { ibu }}{O} \frac{\text { di kamar }}{K}$. Based on its syntactic function, this sentence has SPOSPO pattern. In the second answer, she creates a single sentence with SPOK pattern. Both answers indicate that the student are able to answer the different questions easily. When the researchers ask her the reasons for giving the answer, she explains that she still remembers the learning material about finding the syntactic functions. This can be shown in the following interview script.

P : "Apakah Anda ingat tentang fungsi-fungsi sintaksis?" (Do you remember the syntactic functions?)

S4: "Ya, Pak, saya masih ingat". (Yes, I do remember it.)

$\mathrm{P}$ : "Apakah saudara masih mengingat rumus untuk menemukan fungsi-sungsi sintaksis pada setiap kata?" (Do you still remember how to find the syntactic function of the word?)

S4: "Saya masih mengingat rumus untuk mencari fungsi $S$, $P, O, P e l$., dan $K$ ". (I still remember the way to find the functions of $S, P, O, P e l$., and $K$ )

$\mathrm{P}$ : "Mengapa saudara menjawab dengan jawaban kalimat tunggal dan majemuk?" (why do you answer the questions with single and compound sentences?)

S4: "Saya menjawab berdasarkan soal yang diperintahkan. Saya memiliki strategi dalam menyusun kalimat berdasarkan keilmuan tentang sintaksis. Strategi tersebut diantaranya adalah bahwa 1) kata-kata yang terdapat memang bisa disusun menjadi kalimat tunggal dan majemuk, 2) untuk menunjukkan fungsi sintaksisnya, fungsi $S$ dicari dengan kata tanya siapa untuk benda hidup dan apa untuk benda mati, fungsi $P$ dicari dengan kata tanya mengapa, dan fungsi $O$ berada setelah $P$ dengan predikat yang memiliki imbuhan me-atau di-, fungsi Pel. bisa mengganti fungsi $O$ jika Predikat mengandung imbuhan ber-atau ter-. fungsi Pel. akan berapa di belakang fungsi $O$ jika, kalimat itu berobjek. (I give the answers based on the directions. I have strategies in arranging sentences based on syntax. My strategies are 1) the words given can be arranged into single and compound sentences, 2) to show its syntactic functions, the function of $S$ is found by using the question word "who' or "what", the function of $P$ is found by using the question word "why", and the function of $O$ is after $P$ and the predicate has prefix $m e$ - or $d i-$, the function of $\mathrm{Pel}$. can replaced $O$ when the predicate has prefix $b e r-$ or ter-. And the function of Pel.is after the function of $O$ when the sentence has an object.)

In ATC 4, the students can be said to be very creative in making compound, complex, and compound complex sentences. Before making these sentences, they have to guess firstly the three images as follows. 


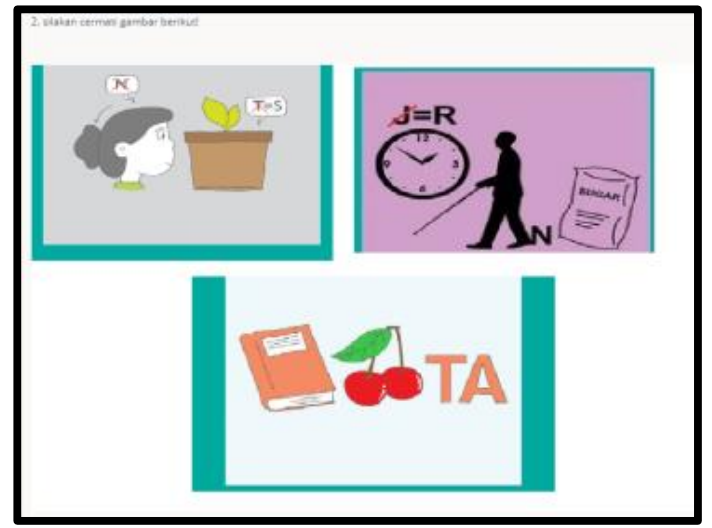

(a)

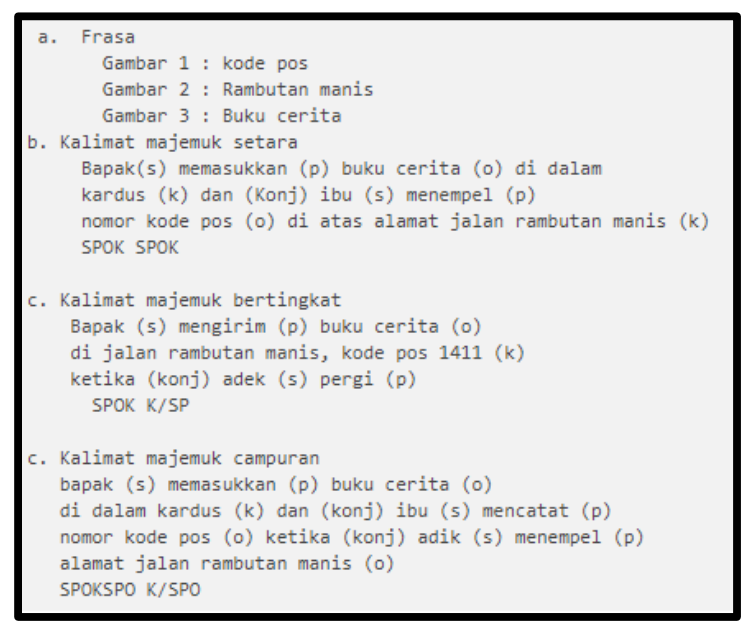

(b)

Figure 6. a) The images of sentences that contain phrases; b) The answer of the $5^{\text {th }}$ student

The images will form phrases. Moreover, it will be arranged into compound, complex, and compound complex sentences. In this level, the students are able to make sentences with different form flexibly based on the images given. The answer can be seen in the following picture.

Based on the images given, the students are able to find the phrases. The first image is kode pos, the second is rambutan manis, and the third is buku cerita. These phrases are used to create compound, complex, and compound complex sentences. In compound sentence, the student writes "Bapak memasukkan buku cerita di dalam kardus dan ibu menempel nomor kode pos di atas alamat jalan rambutan manis". It has SPOK SPOK pattern. In complex sentence, the student writes "Bapak mengirim buku cerita di jalan rambutan manis, kode pos 1411 ketika adek pergi”. This sentence has a main clause "Bapak mengirim buku cerita di jalan rambutan manis, kode pos 1411" and a subordinate clause "adek pergi". It has a pattern of $S P O K \frac{K}{S P}$. In compound complex sentence, the student writes "Bapak memasukkan buku cerita di dalam kardus dan ibu mencatat nomor kode pos ketika adik menempel alamat jalan rambutan manis". It has a main clause "Bapak memasukkan buku cerita di dalam kardus dan ibu mencatat nomor kode pos" and a subordinate clause "Adik menempel alamat jalan rambutan manis". It has a pattern of SPOKSPO $\frac{K}{S P O}$. Using the images to find the phrases and arranging sentences in a good order indicate that the students are very creative in this level.
When the researchers ask the student about the reasons for giving the answer, he explains that he gets it from a process of thinking creatively. It can be shown in the following interview script.

$\mathrm{P}$ : "Apakah sebelumnya saudara pernah main tebak gambar?" (Have you ever played a game of guessing the pictures?)

S5 : "Pernah, Pak". (Yes, I have.)

$\mathrm{P}$ : "Apakah gambar yang saya berikan sudah pernah saudara lihat?" (Have you ever known those images before?)

S5 : "belum, Pak”. (Not yet.)

$\mathrm{P}$ : "Mengapa Saudara bisa menjawab ketiga gambar tersebut" (How can you find the phrases using those images?)

S5 : "Saya berusaha mengamati dan menganalisis masingmasing gambar tersebut dengan teliti dan hati-hati, berkat ketelitian itulah, jawaban-jawaban itu muncul". (I try to observe and analyse every image carefully, then I find the answers.)

$\mathrm{P}$ : "Mengapa saudara bisa menyusun frasa-frasa menjadi kalimat majemuk setara, bertingkat, dan campuran?" (How can you make sentences using the phrases?)

S5 : "Kami selalu dilatih di dalam aplikasi Schoology untuk membuat suatu kalimat dengan memberikan pola yang benar, berdasar pada latihan dan pengalaman yang saya milikilah, saya berusaha memunculkan ide-ide kreatif dalam menyusun kalimat dari frasa-frasa itu, di sini saya butuh ketelitian agar kalimat yang saya tulis benar-benar mengandung frasa-frasa itu, dan yang paling utama, saya harus mampu membedakan antara kalimat majemuk setara, bertingkat, dan campuran dari masing-masing konjungsi yang sudah saya pelajari. (we are always trained to make a good sentence in schoology apps. Having many experiences and training makes me have creative ideas, I have to be carefully to build sentences that include those phrases. The main point is that I have to be able to distinguish between compound, complex, and compound complex sentences based on its conjunctions.)

\subsection{Discussion}

Based on the level of ability to think creatively (ATC) by Tatag, each level that shows the students' creative thinking ability will be discussed. It is viewed from the student's level of metacognitive awareness in syntax subject that implements SSCS learning using schoology apps.

In ATC 0 , the students seem to be not creative. They are unable to modify the words in the song lyrics. The lyric of a song, according to Astute et.al, is an expression of something seen, heard, and experienced that causes emotion as a criteria in finding it [28]. The uncreativity in finding the syntactic functions of the lyrics indicate that they have tacit use level in metacognitive awareness. It can be viewed from the student's way in answering the question without thinking whether it is correct or not.

In ATC 1, the students seem less creative, they have not been able to answer compound words correctly. In this level, they still give the same answers between compound words and idioms. The compound word is a combination of two words or more that has a meaning, the example of compound 
words are 'rumah duka' and 'tutup usia' [29, 30]. Idiom can be stated as a process of creating a meaning that involves think, language symbols [31]. Baryadi adds that the aspect of semantics will define the differences of idiom and non-idiom [32]. The formula of idiom is $\mathrm{A}+\mathrm{B}$ means $\mathrm{C}$, e.g, 'membanting' (A) 'tulang' (B) means 'bekerja keras' (C). On the other hand, the formula of non-idiom is $\mathrm{A}+\mathrm{B}$ means $\mathrm{AB}$, e.g 'membakar' (A) 'kemenyan' (B) means 'tindakan membakar benda berupa kemenyan' $\mathrm{AB}$. The uncreativity in making the examples of compound words indicates that the student has tacit use level of metacognitive awareness. It can be viewed from the answers given by the students are trials and errors. They have not realised that their answers are incorrect.

In ATC 2, the students are quite creative in answering the question about single and compound sentences. They are able to distinguish between them, and able to give the syntactic functions of the sentences correctly. Single sentence is a sentence that has a clause and a constituent of SubjectPredicate [33]. The example of single sentence is $\frac{\text { Dia berjalan }}{S} \frac{\text { b }}{P(V \text { int })}$ and $\frac{\text { Gadis itu sangat cantik }}{S} \quad$ [34]. Compound sentence is a combination of two single sentences or more in which has equal position [35]. The example of of compound sentence is 'cat warna kelasku putih dan gorden kelasku berwarna hijau' [36]. The creativity in answering the questions indicates that the students have aware use level of metacognitive awareness. It can be proved that they are able to use their thinking and awareness in distinguishing between single and compound sentences. They are able to solve the problems correctly.

In ATC 3, the students are creative in answering the questions given. They have strategies in creating two different sentences using the words provided. In this level, the students can be stated to have creative strategy in giving variative answers. They are able to use suitable strategies for different problems. In ATC 3, the students have strategic use level of metacognitive awareness. A study of Sophianingtyas and Sugiarto explain that the students that have strategic use level understand the way to solve the problem and are able to define the strategy used in solving it [37].

In ATC 4, the students are very creative in finding the phrases and arrange it to be compound sentences. Through creativity, they are able to find phrases based on the images in the application. Furthermore, they can make compound, complex, and compound complex sentences correctly. Complex sentence is sentence that has subordinates in the dependent clause [38]. The example of complex sentence is 'Kaisar memberikan sejumlah uang muka yang besar kepada kedua penipu itu agar mereka segera memulai pekerjaan mereka" [39]. The compound complex sentence can be defined as a combination between compound and complex sentences [40]. The example of compound complex sentence is 'Setelah mereka keluar kelas, aku memutuskan mengejar mereka dan berharap mereka mengizinkanku untuk ikut makan di kantin' $126 / \mathrm{IV} / \mathrm{KMK} / \mathrm{K}$ [41]. In this level, the students are very creative. They belong to have reflective use level of metacognitive awareness. It can be viewed from their abilities in finding the phrases of images. Their answers are reflected in compound, complex, and compound complex sentences. They realise to revise the errors in making it.

The relationship between the ability to think creatively (ATC) and the level of metacognitive awareness can be shown in the following table.

The table below shows that when the students' ability to think creatively in answering the questions of syntax subject in schoology apps is getting higher, their level of metacognitive awareness proceed to the reflective use level. Reflective use level has been had by 'climber' student in solving mathematics problem about PISA, they are able to understand, solve, and evaluate the problems [42]. They use their awareness and thinking ability in planning, observing, and evaluating the results of cognitive activities, so they get knowledge in solving the problems [43, 44]. The student's cognitive skill is getting higher, their metacognitive awareness level is getting higher too [45]. The student that have high ability may have both reflective use and strategic use level of metacoginiton awareness.

Table 4. The relationship between ATC and the level of metacognitive awareness

\begin{tabular}{cccccc}
\hline & & \multicolumn{4}{c}{ The level of metacognitive awareness } \\
\cline { 3 - 5 } No. & ATC & $\begin{array}{c}\text { Tacit } \\
\text { use }\end{array}$ & $\begin{array}{c}\text { Aware } \\
\text { use }\end{array}$ & $\begin{array}{c}\text { Strategic } \\
\text { use }\end{array}$ & $\begin{array}{c}\text { Reflective } \\
\text { use }\end{array}$ \\
\hline 1. & ATC"0" & $\sqrt{ }$ & & & \\
2. ATC"1" & $\sqrt{ }$ & & & \\
3. ATC"2" & & $\sqrt{ }$ & & \\
4. ATC"3" & & & $\sqrt{ }$ & \\
5. & ATC"4" & & & & $\sqrt{ }$ \\
\hline
\end{tabular}

\section{CONCLUSIONS}

The conclusions of this study are 1) in ATC 0 , the students are not creative, they have tacit use level of metacognitive awareness, 2) in ATC 1, the students seem to be less creative, they have tacit use level of metacognitive awareness, 3) in ATC 2, the students are quite creative, they have aware use level of metacognitive awareness, 4) in ATC 3, the students are creative, they have strategic use level of metacognitive awareness, 5) in ATC 4, the students are said to be very creative, they have reflective use level of metacognitive awareness.

\section{ACKNOWLEDGMENT}

This work is supported by LPPM Universitas Sebelas Maret and LPPM IKIP PGRI Bojonegoro.

\section{REFERENCES}

[1] Fisher, R. (1995). Teaching Children to Think. London: Stanley Thornes Ltd.

[2] LTSIN. (2004). Learning teaching. Scotland: Learning and Teaching Scotland.

[3] Evans, J.R. (1991). Creative Thinking in the Decision and Management Sciences. Cincinnati: South-Western Publishing Co.

[4] Olson, R.W. (1996). Seni Berpikir Kreatif. Sebuah Pedoman Praktis. (Terjemahan Alfonsus Samosir). Jakarta: Penerbit Erlangga.

[5] Tatag. (2009). Level of student's creative thinking in classroom mathematics. educational research and review. Educational Research and Reviews, 6(7): 548553.

[6] Hong, E. (2014). Creative thinking abilities: Measures 
for various domains. Teaching and Measuring Cognitive Readiness: 201-222. https://doi.org/10.1007/978-1-4614-7579-8_11

[7] Peleg, Z.R., Lesgold, A.M., Pellegrino, J.W., Fokkema, S.D., Glaser, R. (1979). Cognitive psychology and instruction. The American Journal of Psychology, 92(3): 562. https://doi.org/10.2307/1421580

[8] Suherman, E. (2001). Strategi Pembelajaran Matematika Kontemporer. Bandung: JICA Universitas Pendidikan Indonesia.

[9] Misu, L. (2017). Studi tentang kesadaran berpikir metakognisi mahasiswa semester I jurusan pendidikan matematika FKIP UHO. Journal Phenomenon, 7(2): 119-128.

[10] Amin, I. Sukestiyarno, Y.L. (2015). Analysis metacognitive skills on learning mathematics in high school. International Journal of Education and Research, 3(3): 213-222.

[11] Swartz, R.J., Perkins, D.N. (1990). Teaching Thinking. 1st Edition, Routledge, London https://doi.org/10.4324/9781315626468

[12] Kuhn, D. (2000). Theory of mind, metacognitive and reasoning: A life-span perspective. Children's Reasoning and The Mind: 301-326.

[13] Flavell, J.H. (1992). Metacognitive and cognitive monitoring, a new area of cognitive-developmental inquiry. American Psychologist, 34(10): 906-911. https://doi.org/10.1037/0003-066X.34.10.906

[14] Sharples, J., Mathews, B. (1989). Learning how to learn: Investigasi effectif learning strategies. Victoria: Office of Schoolls Administration Ministry of Education.

[15] Collins, N.D. (1994). Metacognitive and Reading to Learn. New York: ERIC Clearinghouse on Information Resources Syracusa.

[16] Chen, W.H. (2013). Applying problem-based learning model and creative design to conic-sections teaching. International Journal of Education and Information Technologies, 3(7): 73-80.

[17] Pizzini, E.L. (1996). Implementation Handbook for The SSCS Problem Solving Instructional Model. Iowa: The University of Iowa.

[18] Irwan, O. (2011). Pengaruh pendekatan problem posing model search, solve, create and share (SSCS) dalam upaya meningkatkan kemampuan penalaran matematis mahasiswa matematika. Journal Penelitian Pendidikan, 12(1): 1-13

[19] Utami, R.P., (2011). Pengaruh model pembelajaran search solve create and share (SSCS) dan problem based instruction (PBI) terhadap prestasi belajar dan kreativitas siswa. Bioedukasi, 4(2): 57-71.

[20] Sicat, A.S. (2015). Enhancing college student's proficiency in business writing via schoology. International Journal of Education and Research, 3(1): $159-178$

[21] Biswas, S. (2013) Schoology-supported classroom management: A curriculum review. Northwest Journal of Teacher Education, 11(2): 1-10.

[22] Aminoto, T. (2014). Penerapan media e-learning berbasis schoology untuk meningkatkan aktivitas dan hasil belajar materi usaha dan energi di kelas XI SMA N 10 kota jambi. Journal Sainmatika, 8(1): 13-29.

[23] Putri, M.A., Jampel, N., Suartama, I.K. (2014). Pengembangan E-learning berbasis schoology pada mata pelajaran IPA kelas VIII di SMP Negeri 1 sririt.
Journal Edutech Universitas Pendidikan Ganesha, 2(1): $1-11$.

[24] Hidayat, Y.N., Wardono, Rusilowati, A. (2019). Analisis kemampuan literasi matematika ditinjau dari metakognisi siswa dalam pembelajaran synectics berbantuan schoology. PRISMA, Prosiding Seminar Nasional Matematika, 2: 911-916.

[25] Daud, W.A.A.W., dan Ghani, M.T.A. (2017). The acceptance of schoology among early childhood education student at mara poly-tech college (KPTM). Journal of Global Business and Social Entrepreneurship (GBSE), 3(6): 133-142.

[26] Miles, M.B. dan Huberman, A.M. (2007). Analisis Data Kualitatif: Buku Sumber Tentang Metode-Metode Baru. Terjemahan Tjetjep Rohendi Rohidi. Jakarta: Universitas Indonesia Press.

[27] Azwar, S. (2012). Reliabilitas dan Validitas. Yogkarta: Pustaka Belajar.

[28] Astute, L.W., Rachmat, C.A., Lukito, Y. (2017). Implementasi algoritma naïve bayes menggunakan isear untuk klasifikasi emosi lirik lagu berbahasa inggris. Journal Informatika, 14(1): 16-21.

[29] Keraf, G. (1985). Diksi dan Gaya Bahasa. Jakarta: Gramedia.

[30] Sulistyono, Y. (2016). Struktur dan fungsi eufimisme dalam rubrik obituari harian kompas. Leksema, 1(2): 73-80.

[31] Ogden, C.K. dan Richards, I.A. (1989). The Meaning of Meaning. San Diego: Harcort Brace Javanovich, Inc.

[32] Baryadi, I.P. (2013). Idiom yang berunsur Kata Kerja dalam Bahasa Indonesia. Journal Ilmiah Kebudayaan SNTESIS, 7(1): 46-62.

[33] Hasanudin, C. (2018). Kajian sintaksis pada novel sang pencuri warna karya yersita. Journal Pendidikan Edutama, 5(2): 19-30.

[34] Andriana, G., Tarmini, W., dan Wetty, N.N. (2015). Struktur kalimat dalam teks anekdot pada surat kabar tempo edisi November 2014. Journal Kata (Bahasa, Sastra, dan Pembelajarannya), 3(4): 1-12.

[35] Suweta, I.M. (2018). Membangun kalimat tunggal dan kalimat majemuk dalam bahasa bali (kajian deskriptif). Widyacarya, 2(2): 1-9.

[36] Wati, R. and Kistian, A. (2019). Analisis kemampuan siswa kelas $\mathrm{V}$ dalam menggunakan kalimat majemuk pada karangan di SD negeri keude linteung kabupaten nagan raya T.A 2018/2019. Bina Gogik: Journal Ilmiah Pendidikan Guru Sekolah Dasar, 6(1): 57-68.

[37] Sophianingtyas, F., Sugiarto, B. (2013). Identifikasi level metakognitif siswa dalam memecahkan masalah materi perhitungan Kimia. Unesa Journal of Chemical Education, 2(1): 21-27.

[38] Suswandi, I. (2018). Perubahan kata "Tiada" dalam tiga karya sastra: Bustan as-salatin (1640), hikayat siak (1855), dan ketika cinta bertasbih 2 (2009). Journal KATA, 2(1): 80-88.

[39] Septianingtias, V. (2015). Pola kalimat pada kumpulan dongeng gadis korek api karya H.C. andersen (suatu kajian sintaksis). Journal Pesona, 1(1): 42-49.

[40] Arifin, Z., dan Junaiyah. (2008). Sintaksis. Jakarta: PT. Grasindo.

[41] Wardani, R.A.K. (2018). Kompeksitas kalimat dalam novel the secret of detya 2: Back to the secret karya kinta. Bapala, 5(1): 1-14.

[42] Arifin, Z., Kurniasih, N., dan Kurniawan, H. (2018). 
Kemampuan metakognisi siswa climber dalam memecahkan masalah matematika soal PISA. Seminar Nasional Pendidikan Matematika Ahmad Dahlan, 6(1): 301-308.

[43] Rahim, U. (2018). Metakognisi siswa yang bargaya kognitif implusif dan yang bergaya kognitif reflektif dalam memecahkan masalah OpenEnded. Journal
Pembelajaran Berpikir Matematika, 3(2): 42-52.

[44] Ekawati, M., dan Asih E.C.M. (2019). Mathematical reflective thinking process based on cognitive style. IOP Conf. Series: Journal of Physics: Conf. Series, 1-8.

[45] Schraw and Moshman. (1995). Metacognitive Theories. Lincoln: University of Nebraska. 